DOI

\title{
ВИЗНАЧЕННЯ РІВНЯ ІНТОКСИКАЦІЇ ТА ДИСБІОЗУ КИШЕЧНИКА У ХВОРИХ НА РАК ШЛУНКА
}

\author{
๑А. В. Русин, Н. М. Маляр-Газда, Н. В. Бедей, О. М. Одошевська \\ ДВНЗ «Ужгородськй національний університет»
}

РЕЗЮМЕ. У роботі представлені результати зміни показників ендогенної інтоксикації залежно від ступеня дисбіозу товстої кишки в різних стадіях пухлинного процесу. У хворих на рак шлунка комплексна оцінка гематологічних індексів більш інформативна, ніж вивчення простої гемограми, адже дозволяє оцінити розвиток, тяжкість та перебіг ендогенної інтоксикації в залежності від стадії пухлинного процесу у цих хворих. Виявлено прямий зв'язок між стадією раку шлунка та дисбіозом товстої кишки, при збільшенні стадії раку шлунка збільшувалась вираженість дисбіозу товстої кишки.

КЛЮчОВІ СЛОВА: рак шлунка, інтоксикаційний синдром, дисбіоз товстої кишки.

Вступ. Рак шлунка (РШ), незважаючи на стійке зниження рівня захворюваності, $\epsilon$ однією 3 найпоширеніших пухлин як в Україні, так і в інших країнах світу, щорічно він призводить до загибелі більш ніж 600 тис. хворих. Рівень захворюваності на РШ у країнах Євросоюзу становить 20 випадків на 100 тис. населення, смертності - 16 на 100 тис. населення [3, 4]. В Україні у 2011 р. зареєстровано 25,32 випадки захворювання на 100 тис. населення, 62 \% хворих із вперше встановленим діагнозом померли впродовж першого року, тому ця патологія залишається однією з найважливіших медичних та соціально-економічних проблем [5]. Результати лікування поширеного РШ (III-IV стадії) не можна визнати задовільними, оскільки, за даними більшості авторів, лише близько 15-25 \% хворих переживають 5-річний термін $[6,7]$. На момент встановлення діагнозу 70 \% пацієнтів у нашій країні не підлягають оперативному лікуванню у зв'язку з поширеністю пухлинного процесу. Хворим цієї групи проводять поліхіміотерапію.

Необхідно зазначити, що перебіг пухлинного процесу супроводжується формуванням синдрому ендогенної інтоксикації та вторинної імунної недостатності. Ендотоксикоз, як і будь-який токсикоз, - це складний, каскадний, стадійний, здатний до прогресування генералізований процес, який обумовлений накопиченням у кров'яному руслі токсичних речовин у концентраціях, що переважають функціональні можливості природних систем детоксикації. Ці пошкодження, в свою чергу, суттєво модифікують структурнофункціональний стан клітинних та субклітинних мембран, викликають другу хвилю інтоксикації та створюють замкнуте коло даного критичного стану. Тяжкість ендогенної інтоксикації $\epsilon$ непрямим критерієм тяжкості загального стану хворих із різними патологічними процесами. На сьогодні в літературі немає однозначної інформації про те, які показники чи система показників $\epsilon$ загально- доступними та ефективними для оцінки тяжкості прогнозу та рівня ендогенної інтоксикації у онкологічних хворих, зокрема у пацієнтів з РШ, тому вибір параметрів, які мають діагностичну значимість для розпізнавання вираженості ендогенної інтоксикації та оцінки стану хворого в різних клінічних ситуаціях залишається однією із актуальних задач клінічної онкології.

Для оцінки ендогенної інтоксикації запропоновано ряд шкал та систем, які базуються на оцінці клінічних та лабораторних показників у балах (SOFA, SAPS, APACHE та ін.). Однак життєве визначення показників, які входять у ці системи, не завжди доступне, що пов'язано з можливостями лабораторних служ6, а також з тривалістю обстеження та оцінкою його результатів у бальній системі, яка часом $\epsilon$ суб'єктивною. Тому в літературі все частіше з'являються повідомлення про використання інтегральних показників інтоксикації. їх використання дозволяє оцінити в динаміці стан різних ланок імунної системи без використання спеціальних методів обстеження. Йдеться про можливість багатогранної оцінки динаміки гомеостазу та ефективності проведеного лікування за даними загального клінічного аналізу крові, який проводять у всіх без винятку лікувальних закладах.

Ендогенна інтоксикація в багатьох випадках супроводжується дисбіотичними розладами. У сучасній літературі розрізняють два види дисбіозу - тонкокишковий та товстокишковий, їх також можна розглядати як один загальний синдром дисбіоз кишечника [1].

Мікрофлору кишечника поділяють на: облігатну- неспороутворювальні анаероби (біфідо- і лактобактерії, бактероїди), які постійно входять до складу нормальної мікрофлори та складають до 98 \% мікрофлори кишечника; факультативну - анаеробні бактерії (кишкова паличка, стрептокок тощо), які часто зустрічаються у здорових 
Огляди літератури, оригінальні дослідження, погляд на проблему

людей, але є умовно-патогенними, близько 1-4 \%; транзиторну (залишкову, випадкову, алохтонну) - мікроби, які зустрічаються в кишечнику спорадично (стафілококи, протей, клостридії, дріжджоподібні гриби, клебсієли тощо), питома вага яких складає 0,01-0,001 \% [2].

Деякі автори пропонують розрізняти в мікробіоценозі товстої кишки цукроволітичні бактерії (біфідо- та лактобактерії, ентерококи), безумовно корисні для людини; протеолітичні бактерії (бактероїди, протей, клостридії, деякі штами кишкової палички), які в деяких випадках можуть стати шкідливими для здоров'я людини [1].

Зниження детоксикаційної функції мікрофлори ШКТ призводить до того, що кров із токсинами із кишечника надходить ворітною веною в печінку, збільшуючи навантаження на їі ферментні системи та призводячи до метаболічних та структурних пошкоджень гепатоцитів. Мікрофлора ШКТ, як «екстракорпоральний орган» детоксикації, подібно до печінки, захищає організм від токсичних впливів продуктів метаболізму

Необхідно зазначити, що проблема зниження пухлинної інтоксикації та корекції кишкового дисбіозу з метою проведення повноцінних курсів хіміотерапії та покращення якості життя пацієнтів з онкопатологією $\epsilon$ однією із актуальних проблем клінічної онкології сьогодення.

Мета. Вивчити зміни показників ендогенної інтоксикації залежно від стадії пухлинного процесу у хворих на рак шлунка, а також визначити значимість цих показників для оцінки розвитку ендогенної інтоксикації та тяжкості загального стану. Оцінити кількісний та якісний стан мікрофлори товстої кишки у хворих на рак шлунка.

Матеріал і методи дослідження. Ми спостерігали за 100 пацієнтами з верифікованим діагнозом РШ, які перебували на лікуванні у Закарпатському обласному онкологічному диспансері за період 2013-2015 рр. За стадіями патологічного процесу пацієнти були поділені наступним чином: у 15 пацієнтів була II стадія, у 44 - III стадія, у 41 IV стадія пухлинного процесу.

Усім обстежуваним проводили загальний аналіз крові з підрахунком формули на момент поступлення в стаціонар для діагностики та лікування. Рівень ендогенної інтоксикації визначали за допомогою індексів інтоксикації: лейкоцитарного індексу інтоксикації (ЛІІ), гематологічного індексу інтоксикації (ГІІ), ядерного індексу інтоксикації (яІІ). Наявність інтоксикації, пов'язаної 3 інфекційним або автоімунним процесом, оцінювали за індексом співвідношення лейкоцитів та ШОЕ (ІЛШОЕ), лімфоцитарно-гранулоцитарним індексом (ІЛГ), а взаємовідношення гуморальної та клітинної ланок імунної системи - за значен- ням лейкоцитарного індексу (ЛІ). Як маркер реактивності організму при запальному процесі використовували індекс зсуву лейкоцитів крові (ІЗЛК). Рівень компенсованості ендогенної інтоксикації визначали за реактивною відповіддю нейтрофілів (РВН). Концентрацію в крові креатиніну та сечовини визначали біохімічними загальновідомими уніфікованими методами.

Після закінчення дослідження був проведений статистичний аналіз отриманих результатів. Результати представлені у вигляді $\mathrm{M \pm m}$, де $\mathrm{M}$ середн $\epsilon$ значення та $\mathrm{m}$ - його похибка. Порівняння середніх значень проводили з використанням t-критерію Стьюдента. Відмінності вважали статистично достовірними при р менше 0,05.

Дослідження видового та кількісного складу мікрофлори товстої кишки проводили методом посіву десятикратних розведень $\left(10^{-1}-10^{-9}\right)$ на стандартний набір елективних та диференційнодіагностичних живильних середовищ для виділення аеробних та анаеробних мікроорганізмів.

Взяття калу проводили в стерильний посуд, що герметично закривається (посуд надавала мікробіологічна лабораторія). Збір калу проводили дотримуючись стерильності. Пробу для дослідження брали із останньої порції фекалій. Кількість зібраного матеріалу становила 1-3 г (об'єм фекалій приблизно як квасолина). Аналіз на дисбіоз набирали у хворих на рак шлунка при поступленні.

Ступінь дисбіозу кишечника оцінювали за класифікацією І. Б. Куваєвої, К. С. Ладодо (1991р.):

1 ступінь характеризується зниженням на 1-2 рівні кількості біфідо-та лактобактерій;

2 ступінь характеризується зниженням на 3-4 рівні кількості біфідо- та лактобактерій та підвищенням кількості умовно-патогенної флори стафілококків, протею; умовно-патогенна флора може мати гемолітичні властивості;

3 ступінь характеризується значним зниженням кількості анаеробів (біфідо- та лактобактерій) та поступовим підвищення кількості аеробів; умовно-патогенна флора набуває агресивних властивостей;

4 ступінь характеризується значними змінами співвідношень облігатнихта факультативних мікроорганізмів, різким зниженням функцій кишкової флори, активацією умовно-патогенної флори.

Результати й обговорення. Пацієнтів віком 21-39 років було 10 (10\%), 40-59 років - 55 (55\%) та старших за 60 років - 35 (35\%). Серед них чоловіків було 67 (67\%), жінок - 33 (33\%).

Для оцінки вираженості ендогенної інтоксикації у хворих на РШ залежно від стадії пухлинного процесу були вивчені дані загального аналізу крові та рівні креатиніну й сечовини (табл. 1). 
Огляди літератури, оригінальні дослідження, погляд на проблему

Таблиця 1. Значення розрахункових показників інтоксикації та рівнів креатиніну і сечовини у хворих на РШ залежно від стадії пухлинного процесу

\begin{tabular}{|l|c|c|c|c|}
\hline Показник & Норма & $\begin{array}{c}\text { II стадія } \\
(\mathrm{n}=15) \\
\mathrm{M} \pm \mathrm{m}\end{array}$ & $\begin{array}{c}\text { III стадія } \\
(\mathrm{n}=44) \\
\mathrm{M} \pm \mathrm{m}\end{array}$ & $\begin{array}{c}\text { IV стадія } \\
(\mathrm{n}=41) \\
\mathrm{M} \pm \mathrm{m}\end{array}$ \\
\hline ЛІІ & $0,3 \div 1,6$ & $2,33 \pm 0,22^{*}$ & $2,59 \pm 0,30^{*}$ & $2,79 \pm 0,23^{*, 2}$ \\
\hline ГІІ & $0,6 \div 0,8$ & $0,7 \pm 0,2$ & $0,9 \pm 0,32$ & $1,2 \pm 0,25^{*}$ \\
\hline ЯІІ & $0,05 \div 0,1$ & $0,15 \pm 0,03$ & $0,19 \pm 0,02^{*}$ & $0,22 \pm 0,03^{*, 2,3}$ \\
\hline ІЛШОЕ & $1,1 \div 2,65$ & $1,65 \pm 0,26$ & $2,84 \pm 0,34$ & $3,29 \pm 0,35^{*, 2,3}$ \\
\hline ІЗЛК & $1.4 \div 2.5$ & $3,00 \pm 0,23^{*}$ & $3,32 \pm 0,31^{*}$ & $3,64 \pm 0,29^{*, 2}$ \\
\hline ІЛГ & $4,2 \div 5,0$ & $3,44 \pm 0,50^{*}$ & $3,03 \pm 0,23^{*}$ & $2,50 \pm 0,27^{*, 2,3}$ \\
\hline ЛІ & $0,35 \div 0,45$ & $0,36 \pm 0,05$ & $0,32 \pm 0,03^{*}$ & $0,26 \pm 0,03^{*, 2,3}$ \\
\hline РВН & $8,5 \div 13,0$ & $15,5 \pm 3,6$ & $18,3 \pm 3,6^{*}$ & $22,5 \pm 2,6^{*, 2}$ \\
\hline Креатинін мкмоль/л & $50 \div 115$ & $86,0 \pm 4,6$ & $89,5 \pm 4,5$ & $108,5 \pm 8,7$ \\
\hline Сечовина ммоль/л & $4,2 \div 8,3$ & $6,4 \pm 0,3$ & $6,2 \pm 0,4$ & $7,8 \pm 0,6$ \\
\hline
\end{tabular}

Примітки: * 1. p <0,05 в порівнянні з нормою; 2. p<0,05 в порівнянні з хворими із ІІ стадією; 3. p<0,05 в порівнянні з хворими із III стадією пухлинного процесу.

У хворих з ІІ стадією пухлинного процесу виявлено достовірні зміни деяких індексів відносно норми, так, ЛІІ визначався на рівні $(2,33 \pm 0,22)$, що характерно для середнього ступеня інтоксикації. Виявлене у хворих з ІІ стадією РШ підвищення ІЗЛК $(3,00 \pm 0,23)$ з одночасним зниженням ІЛГ $(3,44 \pm 0,50)$ дозволяє розмірковувати, що при II стадії пухлинного процесу визначається як ендогенна інтоксикація, так і порушення імунологічної реактивності внаслідок аутоінтоксикації організму.

У пацієнтів з III стадією РШ виявлено тенденцію до зростання розрахункових показників інтоксикації, вони достовірно вказували на наявність інтоксикації, порівняно з нормою, однак статистично вони не відрізнялися від відповідних показників у хворих з ІІ стадією. Визначення середнього значення РВН в інтервалі $15 \div 25$, дозволяє вважати, що у цих хворих ендогенна інтоксикація знаходиться у субкомпенсованому стані.

Найбільш значними зміни розрахункових показників виявилися у хворих на IV стадію РШ, що вказувало на наявність інтоксикації середньої тяжкості. Оцінка змін цих показників вказувала на порушення взаємовідношень між гуморальною та клітинною ланками імунної системи.

Як видно з таблиці 1, середні рівні креатиніну та сечовини при всіх стадіях пухлинного процесу визначаються в межах норми. При цьому спостерігається певне підвищення рівнів у хворих $з$ IV стадією РШ. Однак ми вважаємо, що використання значень креатиніну та сечовини в якості маркерів ендогенної інтоксикації у хворих на РШ $\epsilon$ малоінформативним.

Враховуючи результати проведеного дослідження можна прийти до висновку, що у хворих на РШ комплексна оцінка гематологічних індексів більш інформативна, ніж вивчення простої гемограми. Вона дозволяє оцінити розвиток, тяжкість та перебіг ендогенної інтоксикації залежно від стадії пухлинного процесу у цих хворих.

Результати клінічних спостережень та бактеріологічних досліджень показали, що дисбіоз товстої кишки наявний у 96 \% хворих на рак шлунка. Патологічні зсуви у складі облігатної мікрофлори, які характеризувалися дефіцитом або повним зникненням біфідо- та лактобактерій, ми спостерігали у $94(97,9 \%)$ та 89 (92,7 \%) хворих. Зміни у складі представників колі-флори з дисбалансом в кількісному та якісному відношеннях були у 72 $(75,0 \%)$ та 54 (56,2 \%) хворих, при цьому з проявами агресії - гемоліз еритроцитів констатовано у $37(38,5 \%)$ хворих. Умовно патогенну кишкову флору виявили у 39 (40,6 \%) хворих.

Появу в мікробному складі більше допустимої норми представників роду Proteus спостерігали у 14 (1,6\%) хворих та грибів роду Candida -y $27(28,1 \%)$ хворих, появу золотистого стафілокока -у $18(18,8 \%)$ хворих.

у більшості хворих (54 (56,3\%)) на рак шлунка констатовано асоціативний дисбіоз кишечника, обумовлений мікробною асоціацією з 2-3 представників умовно патогенної флори (табл. 2).

Таким чином, у більшості хворих на рак шлунка виявлено стійкі патологічні зсуви мікроекології товстої кишки, які характеризувалися зміною загальної кількості типових кишкових паличок, появою гемолітичних кишкових паличок, дефіцитом основних представників мікробного пейзажу - біфідобактерій та лактобактерій, збільшенням кількості гнилісних та грибкових бактерій. 
Огляди літератури, оригінальні дослідження, погляд на проблему

Таблиця 2. Зміни мікрофлори товстої кишки у хворих на РШ

\begin{tabular}{|l|c|c|}
\hline \multicolumn{1}{|c|}{ Показник } & Норма & $\mathrm{N}=96(\%)$ \\
\hline Біфідобактерії < $10^{7}$ & $10^{7}$ і вище & $84(97,9)$ \\
\hline Лактобактерії < $10^{6}$ & $10^{6}$ і вище & $72,7)$ \\
\hline Знижена загальна кількість E. coli & $300-400 \mathrm{Mлн/г}(75,0)$ \\
\hline Слабоферментативна E. coli & до $10 \%$ & $54(56,2)$ \\
\hline Гемолітична кишкова паличка & немає & $37(38,5)$ \\
\hline Умовно-патогенні ентеробактерії & немає & $39(40,6)$ \\
\hline Гриби роду Саndida & до $10^{3}$ & $27(28,1)$ \\
\hline Кількість патогенного стафілокока & до $10^{3}$ & $18(18,8)$ \\
\hline Кількість Ргоtеus & до $10^{4}$ & $14(14,6)$ \\
\hline
\end{tabular}

Формування дисбіозу товстої кишки у хворих на рак шлунка можна пояснити зривом адаптаційних, захисних, компенсаторних механізмів, при якому макроорганізм не встигає виробляти ефективні захисні механізми від токсичних субстратів, у результаті чого виникають дисбіотичні порушення кишечника різного ступеня тяжкості.

Порушення видового стану нормальної мікрофлори за участю грибів Candida $\epsilon$ характерним при дисбіозі кишечника у хворих на рак шлунка, що підтверджується високим відсотком їх присутності в наших спостереженнях - 28,1\%.

У таких пацієнтів часто відмічається пригнічення всіх показників імунітету. Як відомо, існує тісний зв'язок між станом імунітету та кандидозом. Кандидоз може бути як наслідком, так і причиною імунної недостатності, що сприяє генералізації кандидозної інфекції. Наведені вище дані дають підставу стверджувати, що застосування імунокоректорів, як і антифунгінальних засобів, $\epsilon$ обов'язковим у корекції дисбіотичних порушень у даної категорії пацієнтів.

У структурі кишкового дисбіозу у обстежених хворих певне місце посідають дисбіотичні порушення, обумовлені бактеріями роду Proteus. Дисбактеріоз товстої кишки, обумовлений бактеріями роду Proteus, виявлено нами у 14,6 \% хворих.

У пацієнтів з ІІ ст. раку шлунка дисбіозу не було виявлено у 4 (26,7 \%) пацієнтів, дисбіоз І ступеня виявлено у 9 (60\%) хворих, дисбіоз ІІ ступеня - у 2 (13,3 \%) хворих. У пацієнтів з ІІІ ст. РШ дисбіозу не виявлено у 1 (2,3 \%) пацієнта, дисбіоз I ступеня виявлено у 14 (31,8 \%) хворих, дисбіоз ІІ ступеня - у 23 (52,3\%) хворих, дисбіоз III ступеня - у чотирьох $(9,1 \%)$ хворих та дисбіоз IV ступеня - у двох (4,5 \%) хворих. У пацієнтів з IV ст. РШ було виявлено дисбіоз I ступеня - у 12 (29,3 \%) пацієнтів, дисбіоз ІІ ступеня - у 14 (34,1 \%) пацієнтів, дисбіоз III ступеня - у 10 (24,4 \%) хворих та дисбіоз IV ступеня -у 5 (12,2 \%) пацієнтів (табл. 3).

Таблиця 3. Ступені дисбіозу у хворих на РШ

\begin{tabular}{|c|c|c|c|c|c|c|c|c|c|c|c|c|c|c|c|}
\hline $\begin{array}{c}\text { Досліджувані } \\
\text { параметри }\end{array}$ & \multicolumn{5}{|c|}{$\begin{array}{c}\text { Пацієнти з ІІ ст. РШ } \\
(\mathrm{n}=15)\end{array}$} & \multicolumn{5}{|c|}{$\begin{array}{c}\text { Пацієнти з III ст. РШ } \\
(\mathrm{n}=44)\end{array}$} & \multicolumn{5}{|c|}{$\begin{array}{c}\text { Пацієнти з IV ст. РШ } \\
\text { (n=41) }\end{array}$} \\
\hline $\begin{array}{l}\text { Ступінь } \\
\text { дисбіозу }\end{array}$ & 0 & 1 & 11 & III & IV & 0 & I & II & III & IV & 0 & I & II & III & IV \\
\hline $\begin{array}{l}\text { Кількість } \\
\text { пацієнтів }\end{array}$ & 4 & 9 & 2 & 0 & 0 & 1 & 14 & 23 & 4 & 2 & 0 & 12 & 14 & 10 & 5 \\
\hline
\end{tabular}

3 даних таблиці 3 чітко прослідковується, що при збільшенні стадійності процесу раку шлунка збільшується ступінь дисбіотичних змін у товстій кишці. Цей факт погіршує перебіг основного захворювання та якість життя пацієнтів. Саме тому вищеперераховані зміни кількісного та якісного складу мікрофлори товстої кишки вимагають корекції: збільшення кількості біфідо- та лактобактерій та зменшення кількості умовно-патогенних бактерій, тому кожен пацієнт повинен мати індивідуальну схему лікування дисбіотичних явищ у кишечнику.

\section{Висновки:}

1. У хворих з І| стадією РШ виявлено достовірні зміни розрахункових індексів відносно норми (ЛІІ визначався на рівні $(2,33 \pm 0,22)$, що характерно для середнього ступеня інтоксикації).

2. У пацієнтів з III стадією РШ виявлено тенденцію до зростання розрахункових показників інтоксикації, однак можна вважати, що у цих хворих ендогенна інтоксикація знаходиться у субкомпенсованому стані. 
Огляди літератури, оригінальні дослідження, погляд на проблему

3. Для хворих з IV стадією РШ характерна наявність ендогенної інтоксикації середнього ступеня важкості.

4. У пацієнтів з ІІ стадією РШ дисбіоз товстої кишки був переважно легкого ступеня (I).

\section{ЛІТЕРАТУРА}

1. Барановский А. Ю. Дисбактериоз и дисбиоз кишечника / А. Ю. Барановский, Э. А. Кондрашина. - СПб., 2000. -209 c.

2. Бондаренко В. М. Дисбактериоз кишечника как клинико-лабораторный синдром: современное состояние проблемы / В. М. Бондаренко, Т. В. Мацулевич. М. : ГЭОТАР-Медиа, 2007. - 304 с.

3. Горбунов В. А. Качество жизни онкологических больных / В. А. Горбунов, В. В. Бредер // IV Ежегодная Рос. онколог. конф. : труды конф. - М., 2000. C. $125-127$.

4. Рак желудка. На пути к решению проблемы /
5. У хворих III стадією РШ переважав дисбіоз товстої кишки середнього ступеня (II).

6. У пацієнтів IV стадією РШ переважав дисбіоз товстої кишки тяжкого ступеня (III та IV).
Г. В. Бондарь, А. Ю. Попович, В. Г. Бондарь [и др.] // Хiрургія України. - 2006. - № 17). - С. 8-12.

5. Рак желудка : профилактика, диагностика и лечение на современном этапе / Г. В Бондарь, Ю. В. Думанский, А. Ю. Попович [и др.] // Онкологія. - 2006. T. 8., № 2. - C. 171-175.

6. Bendell J. Latest data on the treatment of upper gastrointestinal cancers / J. Bendell // ASCO Education Book. - 2008. - P. 184-190.

7. Hwang J. Resectable esophageal, gastroesophageal and gastric cancers: Therapy is distinct for gastric cancer. ASCO / J. Hwang. - Education Book, 2008. - P. 172-176.

\section{STUDYING THE INTOXICATION LEVEL AND COLON DYSBIOSIS IN PATIENTS WITH STOMACH CANCER}

\section{A. V. Rusyn, N. M. Maliar-Hazda, N. V. Bedey, O. M. Odoshevska Uzhhorod National University}

SUMMARY. The paper deals with the results of changes of endogenous intoxication, depending on the degree of colon dysbiosis in various stages of cancer. Comprehensive assessment of hematological indices is more informative than simple study hemogram in patients with stomach cancer, as to evaluate progress, severity and course of endogenous intoxication depending on the stage of tumour in these patients. A direct link between stomach cancer and the stage of colon dysbiosis is discovered, with the increasing of stage of stomach cancer the severity of colon dysbiosis is increasing.

KEY WORDS: stomach cancer, intoxication syndrome, colon dysbiosis. 